\title{
IMPLICIT IGEI ARGUMENTUMOK A MAGYAR NYELVHASZNÁLATBAN
}

Az elmúlt évtizedek nemzetközi szakirodalma nem mondható egységesnek az igei argumentumszerkezetek vizsgálata szempontjából. Ezen a szakterületen alapvetően két ellentétes törekvés határozza meg a nyelvtudományi kutatás irányát. Az egyik irányzat követöi szerint az elméleti nyelvészet egyes részdiszciplínái önmagukban is képesek lehetnek arra, hogy teljes képet alkossanak az igék és az igékhez tartozó grammatikai szerkezetek bonyolult viszonyáról. Példaként említhetnénk az igei argumentumok szintaktikai megfontolásokon alapuló elemzéseit. A szintaktikai elméletalkotók jellemzően a mondat szintjét tekintik az elemzés elsődleges tárgyának, és az igék mondatszerkezetben betöltött strukturális szerepéből vonnak le általánosítható következtetéseket az argumentumok számára és típusára vonatkozóan. Ugyanitt említhetnénk a tisztán pragmatikai elméleteket is, amelyek a nyelvhasználat szintjét tartják elsődleges jelentőségünek a téma szempontjából, és a nyelvhasználók kommunikációra irányuló törekvései alapján próbálják azonosítani az igék argumentumszerkezetét. A másik irányzat követői az egyes nyelvészeti részdiszciplínák módszertani eljárásait és fogalmi eszközeit magyarázati szempontból erősen korlátozottnak tekintik, ezért az igei argumentumokkal összefüggő problémák komplex megközelítését szorgalmazzák. Ez nem jelenti azt, hogy a komplex megközelítésmódot javasló nyelvészeknek az elméleti alapvetések teljes spektrumában feltétlenül azonos álláspontot kell képviselniük. Különböző nyelvészeti hagyományokhoz tartozó és eltérő szakmai érdeklődésủ szerzőkről van szó ebben az esetben, akikben az a közös vonás, hogy az igék viselkedésének rendszerszintü leírásában a szintaktikai, a pragmatikai és a lexikai-szemantikai magyarázati eljárások ötvözésére törekednek.

Angol nyelvủ monográfiájában Németh T. Enikő is az utóbb említett irányzatot követi. A monográfia az igei argumentumokat tárgyaló szakirodalom kritikai áttekintésével kezdődik. Németh T. részletesen tárgyalja azokat a nézeteket, amelyek egy-egy speciális nyelvészeti részdiszciplínához köthetők, és minden esetben világosan indokolja, miért korlátozott az ilyen típusú, lényegében véve egy szempontú elméletek magyarázó ereje. Kritikai áttekintésének végén a szerző arra a következtetésre jut, hogy az igei argumentumok vizsgálatában akkor nyílhat valódi esélyünk egy komplex megközelítés kidolgozására, ha az elméletalkotás első fázisában a nyelvhasználók konkrét nyelvi megnyilatkozásait tekintjük meghatározó adattípusnak. Ez mindenképpen jó módszertani döntésnek tünik, hiszen diskurzusba ágyazottságuk miatt a konkrét nyelvi megnyilatkozások szintaktikai-grammatikai, lexikai-szemantikai, kontextuális és pragmatikai nézőpontból egyaránt vizsgálhatók. 
Amint azt a monográfia címe is világossá teszi, az igei argumentumszerkezetek általános és szerteágazó témáját Németh T. egy jobban áttekinthető, szükebb összefüggésben közelíti meg. Ennek megfelelően a monográfia gerincét alkotó fejezetek az implicit igei argumentumok elemzésére korlátozódnak, és nem lépnek túl a magyar nyelvhasználat különböző formáiban fellelhető adatokon. A nézőpont ilyetén szükítéséből azonban nem következik, hogy kizárólag a magyar nyelvre vagy csak a magyar nyelvhasználatra lennének érvényesek a gondolatmenet főbb pontjain megfogalmazott elméleti állítások. Jellemző példa lehetne erre a monográfia egyik központi elemének, az 'implicit argumentum' fogalmának definíciója, amely semmiképpen sem tekinthető nyelvspecifikusnak: „Implicit argumentum az ige lexikai-szemantikai reprezentációjában szereplő, delexikailag meg nem jelenő argumentum, amelynek implicit jelenlétét a megnyilatkozásokban lexikai-szemantikai, grammatikai (fonológiai, morfológiai, szemantikai és szintaktikai) diskurzus és/vagy pragmatikai bizonyítékok támasztják alá" (67.).

Az imént idézett definíció már önmagában is jelzi a szerző által előnyben részesített komplex szemléletmódot. Mivel egy adott ige valamely argumentuma, sőt, akár összes kötelező és megengedett argumentuma számos ok miatt maradhat rejtett vagy számos ok miatt törlödhet egy konkrét nyelvi megnyilatkozásból, az argumentumok jelenlétét és törlését szabályozó okok rendszeres feltárása nem korlátozódhat egyetlen adattípus vizsgálatára.

A szerző több igeosztályra kiterjedő elemzéssel illusztrálja ennek a felismerésnek a megalapozottságát. A természeti jelenségeket jelölő igeosztállyal kapcsolatban például kimutatja, hogy az olyan kifejezések, mint a ,hajnalodik” vagy a „villámlik”, a hagyományos felfogással ellentétben értelmezhetők alanyi argumentumhellyel rendelkező igékként, ahogyan azt a „Hajnalodik az idő” és a „Villámlik az ég” intuitív értelemben jól formáltnak tekinthető megnyilatkozásai is tanúsítják. A megnyilatkozások nagy többségében az alanyi argumentum azonban rejtett maradhat, mivel természeti jelenségekre vonatkozó tudásukra és az ige lexikai jelentésének ismeretére támaszkodva a nyelvhasználók képesek következtetni arra, hogy milyen típusú kifejezés tölthetné be ilyen esetekben az argumentum szerepét.

Közismert, hogy a magyar nyelvtani irodalom külön osztályba sorolja azokat az igéket, amelyeknek egyszerre létezik tárgyas és tárgyatlan lexikai változata. Ide tartozik többek között az ,eszik”, az „,iszik” vagy az „olvas”. Németh T. ezt a hagyományos értelmezést is korrigálja. Meglátása szerint ennek az igeosztálynak az elemei kivétel nélkül mind tárgyas igék, de az evés, az ivás vagy az olvasás cselekvéséhez kapcsolódó tárgyak bizonyos körülmények között rejtettek maradhatnak. Ilyen körülménynek számít, ha a nyelvhasználók nem tudják megnevezni a cselekvés tárgyát, vagy éppen kommunikatív szempontból nem tartják lényegesnek, hogy megnyilatkozásaikban egyértelműen megjelöljék ezeket a tárgya- 
kat. Érdemes hangsúlyozni, hogy ezzel a korrekcióval lényegesen egyszerübbé és jobban áttekinthetővé tehető az igék hagyományos nyelvtani osztályozása.

A szerző figyelme az igék szükebb csoportjaira is kiterjed, gondos elemzést kapunk például a tárgyas igék perfektív változatairól is. Szembetűnő vonása a monográfiának, hogy az elemzett példák változatossága ellenére a gondolatmenet mindvégig jól követhető és egységes marad. Németh T. következetesen érvel amellett, hogy bármilyen igetípusról is legyen szó, az implicit igei argumentumok viselkedését csak úgy írhatjuk le kimerítően, ha képesek vagyunk a különböző nyelvészeti részdiszciplínák nézőpontjait és adatkezelési módszereit integrálni. Metaelméleti tudatosság nélkül feltehetően nem is létezhetne az elméleti nyelvészetnek ez a válfaja. Nem indokolatlan tehát, hogy az eltérő forrásból származó adatok kezelésében és integrálásában a szerző a Kertész András és Rákosi Csilla által kidolgozott metaelméleti modell, az úgynevezett p-modell felismeréseire támaszkodik.

(Enikö Németh T.: Implicit Subject and Direct Object Arguments in Hungarian Language Use: Grammar and Pragmatics Interacting. Sheffield/Bristol: Equinox, 2019, 268 o.)

Vecsey Zoltán

tudományos fömunkatárs MTA-DE-SZTE Elméleti Nyelvészeti Kutatócsoport, Eötvös Loránd Kutatási Hálózat 